\title{
Validation of the adherence questionnaire for Brazilian chronic kidney disease patients under hemodialysis
}

\author{
Validação do questionário de adesão do paciente renal crônico brasileiro em hemodiálise \\ Validez del cuestionario de adhesión del paciente renal crónico en hemodiálisis para Brasil
}

\section{Silvia Maria de Sá Basilio Lins', Josete Luzia Leite', Simone de Godoy", Patrícia dos Santos Claro Fuly"I, Silvia Teresa Carvalho de Araújo', Ítalo Rodolfo Silva' \\ 'Universidade Federal do Rio de Janeiro, Anna Nery Nursing School. Rio de Janeiro, Brazil. \\ "Universidade de São Paulo, Ribeirão Preto College of Nursing, \\ Department of General and Specialized Nursing. Ribeirão Preto, São Paulo, Brazil. \\ III Universidade Federal Fluminense, Aurora de Afonso Costa Nursing School, \\ Department of Medical-Surgical Nursing. Niteró, Rio de Janeiro, Brazil.}

How to cite this article:

Lins SMSB, Leite JL, Godoy S, Fuly PSC, Araújo STC, Silva IR. Validation of the adherence questionnaire for Brazilian chronic kidney disease patients under hemodialysis. Rev Bras Enferm [Internet]. 2017;70(3):558-65.

DOI: http://dx.doi.org/10.1590/0034-7167-2016-0437

Submitted: 09-02-2016

Approved: 11-26-2016

\section{ABSTRACT}

Objective: To validate the evaluation questionnaire on adherence of chronic kidney disease (CKD) patients under hemodialysis. Method: We verified the following psychometric properties of the instrument: reliability (stability and internal consistency) and validity (face, content, and construct). Results: The intraclass correlation coefficient reached a value of 0.98 for the adherence questions and 0.91 for the perception questions. Regarding the kappa of the 14 questions examined, 12 had a value $>0.8$, whereas the Cronbach's alpha had a value of 0.57. Experts ensured the face and content validity of the instrument, giving it an overall content validity index of 0.96. Construct validity, analyzed by Mann-Whitney test, was achieved as all domains showed a significant association with $p<0.01$. Conclusion: We verified, by the presented results, that the instrument has been validated for use in Brazil. Descriptors: Patient Cooperation; Medication Adherence; Chronic Kidney Disease; Kidney Dialysis; Nursing in Nephrology.

\section{RESUMO}

Objetivo: Validar o questionário de avaliação sobre a adesão do portador de doença renal crônica em hemodiálise. Método: Foram verificadas as seguintes propriedades psicométricas do instrumento: confiabilidade (estabilidade e consistência interna) e validade (de face, de conteúdo e de construto). Resultados: O coeficiente de correlação intraclasse atingiu valor de 0,98 para as questões de adesão e 0,91 para as questões de percepção. Quanto ao kappa das 14 questões analisadas, 12 obtiveram um valor $>0,8$. Já o alfa de Cronbach obteve valor de 0,57. Os especialistas asseguraram a validade de face e de conteúdo do instrumento, conferindo-lhe um índice de validade de conteúdo global de 0,96. A validade de construto, analisada por meio do teste de Mann-Whitney, foi alcançada na medida em que todos os domínios apresentaram uma associação significativa com $p$ $<0,01$. Conclusão: Verifica-se, pelos resultados apresentados, que o instrumento foi validado para uso no Brasil.

Descritores: Cooperação do Paciente; Adesão à Medicação; Insuficiência Renal Crônica; Diálise Renal; Enfermagem em Nefrologia.

\section{RESUMEN}

Objetivo: Comprobar la validez del cuestionario de adhesión del paciente con enfermedad renal crónica en hemodiálisis para Brasil. Método: Se evaluaron las siguientes propiedades psicométricas del instrumento: confiabilidad (estabilidad y consistencia interna) y validez (predictiva, de contenido y de constructo). Resultados: Los valores de la correlación intraclase fueron de 0,98 para las cuestiones de adhesión y de 0,91 para las de percepción. En relación a la kappa de las 14 cuestiones evaluadas, 12 resultaron un valor mayor que 0,8. Mientras que el Alfa de Cronbach fue de 0,57. Los expertos pudieron garantizar la validez predictiva y de contenido del instrumento, en la que el puntaje de validez de contenido global fue de 0,96. Se obtuvo la validez de constructo, evaluada a 
través de la prueba de Mann-Whitney, cuando todos los dominios presentaron una asociación significativa con $p<0,01$. Conclusión: Desde los resultados observados es posible afirmar que el instrumento todavía no tiene validez para emplearse en Brasil.

Descriptores: Cooperación del Paciente; Adhesión a los Medicamentos; Insuficiencia Renal Crónica; Diálisis Renal; Enfermería en Nefrología.

\section{CORRESPNDING AUTHORＳilvia Maria de Sá Basilio LinsＥ-mail: silviamarialins@gmail.com}

\section{INTRODUCTION}

Chronic kidney disease (CKD) is a silent, slow and progressive pathology. This disease requires, for its treatment, a renal replacement therapy (RRT) when it reaches the stage 5 of its evolution - the most advanced one ${ }^{(1)}$. Brazilian data show a prevalence and incidence of 499 and 170 patients per million of the population, respectively, in dialysis treatment. Authors have estimated that, in 2013, 100,397 patients performed RRT, with an annual growth of $3 \%, 90.8 \%$ of them undergoing hemodialysis (HD) and $85 \%$ supported by the Brazilian Unified Health System (SUS) ${ }^{(2)}$.

In the most advanced stage, CKD exposes the individual to a complex therapeutic regimen, which consists of RRT, dietary and liquid restriction, and medication intake. These four aspects of the treatment are inseparable and constitute the therapy pillars, directly affecting morbidity/mortality rates. The non-adherence to one of these variables reflects negatively on the patient's quality of life, as well as on health costs ${ }^{(3)}$.

Several studies present percentage values about the adherence of renal patients undergoing hemodialysis. In a study that measured adherence to medications, $55.4 \%$ of respondents were non-adherent ${ }^{(4)}$; in another research, $50 \%$ of patients reported not adhering to water intake and $44 \%$ did not follow the dietary recommendations ${ }^{(5)}$. Studies that seek to quantify the adherence of these patients find a difficulty common to them all: the impossibility of comparing the results obtained because of the different methods employed to obtain them.

A precise evaluation of the adherence behavior is essential for planning care, allowing changes and adaptations in the prescribed recommendations. In addition, the methodology used for this evaluation shall enable the correlation between the results found and the effects produced by the actions implemented from these results ${ }^{(6)}$. For this, one needs to have a valid and reliable instrument. The literature presents several available tools to measure the degree of adherence, but there is not a better one among them, no gold standard(7).

A research conducted in the LILACS, MEDLINE, and CINHAL databases, in the set of the Doctoral Dissertation that originates this article, identified that, in Brazil, there is no instrument built specifically to measure the adherence of chronic renal patients to the four domains of their treatment (HD, diet, water intake, and medications). Brazilian research often uses generic instruments that address one single aspect of therapy ${ }^{(8)}$.

By restricting the available instruments for measuring the specific adherence of renal patients under hemodialysis, one can find two internationally used scales: Dialysis Diet and Fluid Non-Adherence Questionnaire (DDFQ), which measures liquid and dietetic aspects ${ }^{(9)}$ and The End-Stage Renal Disease
Adherence Questionnaire (ESRD-AQ). The latter is a self-report instrument, developed in Los Angeles, which, in addition to measuring in a valid and reliable way the adherence behavior to the four aspects of the treatment, also assesses the individuals' perception about adherence and the reasons for their adherent/non-adherent behavior ${ }^{(7)}$.

The items of ESRD-AQ were prepared based on the literature and on the consultation with experts. It consists of 46 questions divided into general information and the domains "hemodialysis," "medication," "water restriction," and "diet." The responses contained in the instrument use a combination of Likert scale, multiple choice, and yes/no format. Adherence itself is evaluated in six questions, in which patients are given a score according to the answer presented: the most adherent patients earn more points, unlike the least adherent ones. Eight other questions inquire the individuals' perception about the treatment ${ }^{(7)}$.

For conducting studies on adherence using self-report scales, it is advisable to compare them to some objective parameters ${ }^{(10)}$. In the case of CKD, biochemical and biological markers are used for this purpose - for example, interdialytic weight gain (IWG), phosphorus and potassium levels in pre-hemodialysis, number of absences in the sessions, or the amount of times that these sessions were shortened. It is worth emphasizing that such parameters are used as a reference, not being possible to associate them as determinants of an adherent/non-adherent behavior ${ }^{(11)}$.

Considering that, in dialysis clinics, the nurse/patient ratio is $1 / 35^{(12)}$, the therapeutic regimen management can be facilitated by a technological tool that helps to identify the individuals' adherence behavior. The use of this tool may also contribute to reduce the high mortality rate of renal patients under hemodialysis, which, in Brazil, is about $19.9 \%{ }^{(2)}$. The use of this type of instrument can also strengthen the professional-patient bond, producing a positive effect on the adherence, since therapeutic alternatives can be explored and negotiated ${ }^{(6)}$.

According to the National Kidney Foundation, the ideal hemodialysis dosage is already established worldwide: frequency of three times per week and duration of four hours each session, with the goal of maintaining an urea reduction ratio $(\mathrm{Kt} / \mathrm{V})$ around 1.2. Thus, to achieve mortality rate reduction, it is necessary to focus on research in other areas, including patient adherence to the treatment proposed ${ }^{(13)}$. On its agenda of research priorities, Brazil stimulates studies that can contribute to the reduction of mortality and morbidity rates in this specific population ${ }^{(14)}$.

The lack of instruments to help monitoring CKD patients' adherence to treatment in Brazil was the primary motivation for this study. The existence of a questionnaire that allowed not only distinguishing patients between adherent and non-adherent, but also identifying which aspect of treatment 
represented greater difficulty to the individual, has aroused our interest to validate it to the Brazilian reality.

From the previous cultural adaptation of ESRD-AQ to Brazil, which generated the Questionário de avaliação sobre a adesão do portador de doença renal crônica em hemodiálise $(\mathrm{QA}-\mathrm{DRC}-\mathrm{HD})^{(12)}$, this research aimed to validate this questionnaire for use in Brazil.

\section{METHODS}

\section{Ethical aspects}

This study was approved by the Research Ethics Committee of Anna Nery Nursing School. All recommendations of the Resolution 466/12 from the National Health Council (CNS) were followed. The risks in this research were of psychosocial order, to the extent that participants might feel constrained to respond to the questions contained in the questionnaire. To minimize this possibility, we clarified all possible doubts and provided the necessary information.

\section{Study design, location, and period}

This is a descriptive, cross-sectional study with quantitative approach, which sought to validate the psychometric properties - reliability and validity - of the evaluation questionnaire on adherence of CKD patients on hemodialysis (QADRC-HD), adapted version ${ }^{(8)}$ for Brazil. The research was conducted in two dialysis centers, in the cities of Itaboraí and Niterói, both in the state of Rio de Janeiro. Data collection took place between September 2014 and February 2015.

\section{Population or sample; inclusion and exclusion criteria}

This study had participation of nine experts, thus considered by having at least two years of experience with titles offered by the Brazilian Society of Nephrology, in the case of the three doctors; and two years of experience with master's degree in the field of Nephrology, for the six nurses. Patients from dialysis clinics also participated, with the following inclusion criteria: 1) undergoing HD for more than three months; 2) performing $\mathrm{HD}$ three times a week with duration of three to four hours; 3) being over 18 years; 4) being independent to perform activities such as walking and feeding; 5) being literate; and 6) having no cognitive deficit.

The sample was nonprobabilistic, for convenience. We sought to meet the recommended ${ }^{(15)}$ number of participants for this type of study: a minimum of 50 and a maximum of 100 individuals. In the period established for collection, we were able to approach 78 patients indicated by the nurse in charge of the dialysis centers, to avoid the constraint of those who did not meet the inclusion criteria. All study participants - experts and patients - signed an informed consent form, which was delivered to them in two copies.

\section{Study protocol}

In the reliability analysis, we verified the stability of the instrument by the intraclass correlation coefficient (ICC) and kappa coefficient. To this end, the adopted procedure consisted on test-retest, in which the instrument was applied to 18 patients
(23\% of the total sample) at two different times, with interval of two days between the answers. ICC was verified by comparing the responses obtained in the perception questions (8 questions) and adherence questions (6 questions). The value considered excellent was greater than or equal to $0.80^{(16)}$. For the kappa coefficient, which measures the degree of agreement between tests when the variables are categorical, the values considered excellent were between 0.81 and $1.0^{(17)}$.

Still in the reliability analysis, we also verified the internal consistency of the instrument by the Cronbach's alpha. At this stage, because of the instrument's heterogeneity of responses, the internal consistency was evaluated only between the 6 adherence questions, which had a uniform pattern of responses, based on the Likert scale. We included the 78 participants of the study (full sample), and considered ideal a value between 0.7 and $0.9^{(18)}$.

Face and content validity were verified by a group of nine experts. The evaluation of the former consisted only of quickly and easily verifying whether the instrument seemed to be addressing the topic appropriately, while the evaluation of the latter consisted of specialists receiving the instrument with the sentences and a space for analyzing their thematic relevance. They were also instructed to assign the following scores: 1 = not relevant; 2 = little relevant; 3 = relevant; and $4=$ highly relevant.

Each score had a weight: $1=0.25 ; 2=0.5 ; 3=0.75$; and $4=1$. When all experts returned their instruments, these scores were added and divided by the number of respondents. Thus, the content validity index (CVI) of each sentence, domain and of the instrument as a whole was calculated, considering satisfactory a CVI greater than $0.80^{(19)}$.

Finally, we analyzed construct validity by the technique of known groups, in which the groups allegedly different in terms of target-attribute responded to the questionnaire and, then, the scores obtained between the two groups were compared. The 78 patients were separated between adherent and non-adherent in each domain of the scale, according to their biological markers, accessed on their medical records.

We used the same cutoff points referenced in the original scale $^{(7)}$. For adherence to HD, patients who missed or shortened more than one session in the month before the survey were considered non-adherent; for non-adherence to medication, a phosphorus level greater than $7.5 \mathrm{mg} / \mathrm{dl}$ in the month before the survey was considered; for non-adherence to the dietary regime, patients with phosphorus greater than $7 \mathrm{mg} / \mathrm{dl}$ and/or potassium greater than $6.0 \mathrm{mmol} / \mathrm{dl}$ in the month before the survey were considered non-adherent; for water intake, patients with IWG greater than $5.7 \%$ of their dry weight in more than one session, the week before the survey, were considered non-adherent. The correlation between the two groups and the scores obtained by them in the adherence questions was calculated by Mann-Whitney $U$ test.

\section{Analysis of results and statistics}

ICC, kappa coefficient, Cronbach's alpha, CVI, and MannWhitney $U$ test were performed using the Statistical Package for the Social Sciences SPSS, version 15.0, with the assistance of statistical advice to this end. The data underwent double entry in Excel, for subsequent export to the statistical program. We adopted a 5\% significance level. 


\section{RESULTS}

In the reliability analysis, the adherence and perception questions presented a ICC of 0.98 and 0.91 , respectively, values considered excellent and meaning that the instrument has a high stability, i.e., a good capacity to produce the same responses at different times. The responses submitted by patients for the perception and adherence questions presented few variations, and the scores assigned to patients remained the same between most respondents.

Table 1 - Intraclass correlation coefficient of the perception and adherence questions of the evaluation questionnaire on adherence of chronic kidney disease patients on hemodialysis, Rio de Janeiro, Brazil, 2015

\begin{tabular}{lcc}
\hline Domain & $\begin{array}{c}\text { Intraclass Correlation } \\
\text { Coefficient }\end{array}$ & $\begin{array}{c}\text { Confidence interval } \\
\mathbf{( 9 5 \% )}\end{array}$ \\
\hline Adherence & 0.98 & $0.95 ; 0.99$ \\
Perception & 0.91 & $0.75 ; 0.97$ \\
\hline
\end{tabular}

\section{Kappa - Questions}

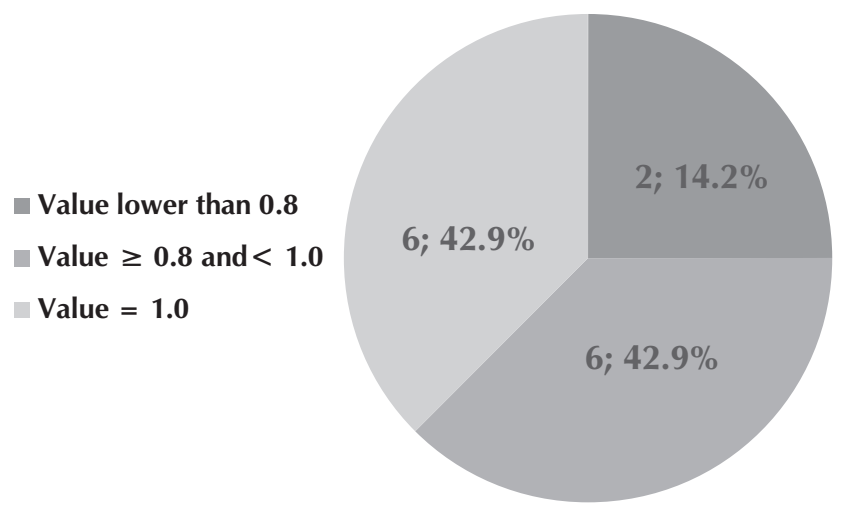

Figure 1 - Kappa coefficient distribution between the perception and adherence questions of the evaluation questionnaire on adherence of chronic kidney disease patients on hemodialysis, Rio de Janeiro, Brazil, 2015

In the evaluation of the kappa coefficient, from the eight questions of perception, six of them presented a value greater than or equal to 0.8 , with two questions presenting 0.45 and 0.79. In turn, in the evaluation of the six adherence questions, all obtained an index greater than 0.8 , and three of them, an index equal to 1.0. The kappa index evaluates each question separately, unlike the ICC, which evaluates a class of questions. Here, one can consider that, in the evaluation of categorical (qualitative) variables, the instrument presented an excellent result, considering that $12(85.8 \%)$ questions presented a kappa greater than or equal to 0.8 , i.e., the degree of agreement between tests was high.

Internal consistency was verified by Cronbach's alpha, with a value of 0.57 , considered not satisfactory. It is worth highlighting that the alpha serves to assess the magnitude with which the instrument's items relate to each other; however, although the six questions measure adherence, they evaluated different aspects of treatment. That is, there is not necessarily a correlation between being non-adherent to HD and nonadherent to water intake (WI), for example.

Face validity was obtained by the consensus and agreement of experts with the questions of the instrument. In the analysis of content validity, all 46 questions obtained a CVI greater than 0.80 . Of these, $20(43 \%)$ questions presented a CVI of 1.0, meaning that all experts assigned the maximum score to the question relevance. When separated by domain, the set of questions regarding hemodialysis obtained a CVI of 0.98 ; the set regarding medication (Med), a CVI of 0.97 ; the set regarding water intake, a CVI of 0.96 ; and the set regarding diet (Die), a CVI of 0.95. The instrument as a whole received a CVI of 0.96 .

Based on the objective data collected from the medical records of the 78 patients who responded to the questionnaire, $25(32 \%)$ of them were considered non-adherent to hemodialysis, $5(6.4 \%)$ to medication, $14(17.9 \%)$ to water restriction, and $11(14.1 \%)$ to dietary restriction. The patients were, therefore, separated into groups of adherence and non-adherence, so that the analysis of their responses allowed determining the instrument's distinction capacity, and thus ensuring its construct validity.

The answers to the adherence questions of the instrument generated scores for patients: the most adherent ones should get a highest score, while the least adherent ones should get a lower score. The correlation was obtained by Mann-Whitney test. All domains presented significant association with $p<0.01$, meaning that the instrument can distinguish patients between adherent and non-adherent, by their answers to it. 
Table 2 - Association between adherent/non-adherent patients and scores obtained in the adherence questions of the evaluation questionnaire on adherence of chronic kidney disease patients on hemodialysis, Rio de Janeiro, Brazil, 2015

\begin{tabular}{|c|c|c|c|c|c|c|c|c|c|c|}
\hline Question & Adherence & $\mathbf{n}$ & Mean & Standard Deviation & Minimum & $1^{\text {st }}$ quartile & Median & $3^{\text {rd }}$ quartile & Maximum & $p$ value \\
\hline \multirow{2}{*}{$\begin{array}{c}\text { Q14 } \\
\text { Hemodialysis }\end{array}$} & Adherent & 53 & 294.34 & 23.33 & 200.00 & 300.00 & 300.00 & 300.00 & 300.00 & \multirow{2}{*}{$<0.01$} \\
\hline & Non-adherent & 25 & 242.00 & 75.94 & 50.00 & 200.00 & 300.00 & 300.00 & 300.00 & \\
\hline \multirow{2}{*}{$\begin{array}{c}\text { Q17 } \\
\text { Hemodialysis }\end{array}$} & Adherent & 53 & 183.02 & 35.28 & 0.00 & 150.00 & 200.00 & 200.00 & 200.00 & \multirow{2}{*}{$<0.01$} \\
\hline & Non-adherent & 25 & 86.00 & 44.53 & 0.00 & 100.00 & 100.00 & 100.00 & 150.00 & \\
\hline \multirow{2}{*}{$\begin{array}{c}\text { Q18 } \\
\text { Hemodialysis }\end{array}$} & Adherent & 53 & 80.66 & 35.57 & 0.00 & 75.00 & 100.00 & 100.00 & 100.00 & \multirow{2}{*}{$<0.01$} \\
\hline & Non-adherent & 25 & 24.00 & 18.37 & 0.00 & 0.00 & 25.00 & 25.00 & 50.00 & \\
\hline \multirow{2}{*}{$\begin{array}{l}\text { Hemodialysis } \\
\text { Subscale }\end{array}$} & Adherent & 53 & 967.45 & 154.23 & 575.00 & 850.00 & 1000.00 & 1100.00 & 1200.00 & \multirow[t]{2}{*}{$<0.01$} \\
\hline & Non-adherent & 25 & 694.00 & 166.97 & 400.00 & 550.00 & 675.00 & 850.00 & 950.00 & \\
\hline \multirow{2}{*}{$\begin{array}{c}\text { Q26 } \\
\text { Medication }\end{array}$} & Adherent & 73 & 177.40 & 44.91 & 0.00 & 150.00 & 200.00 & 200.00 & 200.00 & \multirow{2}{*}{$<0.01$} \\
\hline & Non-adherent & 5 & 30.00 & 44.72 & 0.00 & 0.00 & 0.00 & 50.00 & 100.00 & \\
\hline \multirow{2}{*}{$\begin{array}{c}\text { Q31 } \\
\text { Water Intake }\end{array}$} & Adherent & 64 & 128.91 & 58.29 & 0.00 & 100.00 & 150.00 & 175.00 & 200.00 & \multirow[t]{2}{*}{$<0.01$} \\
\hline & Non-adherent & 14 & 7.14 & 18.16 & 0.00 & 0.00 & 0.00 & 0.00 & 50.00 & \\
\hline Q46 & Adherent & 67 & 126.87 & 64.74 & 0.00 & 100.00 & 150.00 & 200.00 & 200.00 & \multirow{2}{*}{$<0.01$} \\
\hline Diet & Non-adherent & 11 & 27.27 & 60.68 & 0.00 & 0.00 & 0.00 & 50.00 & 200.00 & \\
\hline
\end{tabular}

\section{DISCUSSION}

The adapted version of the questionnaire (QA-DRC-HD) was submitted to the validation of its psychometric properties, so that it was possible to ensure that the instrument would be able to measure what it proposed to. The first evaluated item was reliability, in the stability aspect, measured by testretest applied to 18 patients, calculating the ICC in the classes of questions on perception and adherence, in addition to the kappa coefficient of each of these questions, individually.

Both for the ESRD-AQ ${ }^{(7)}$ and its Spanish version ${ }^{(20)}$, the testretest was conducted with only six patients in each, and, in both, only the ICC was calculated. This index, in the Brazilian version, was 0.98 for the group of adherence questions and 0.91 for the group of perception questions, which are values similar to those obtained in the original (0.91) and Spanish (0.96) versions.

Another index only evaluated in the Brazilian version was the kappa coefficient, which analyzes the capacity of reproducibility based on the number of answers agreeing with each question $^{(21)}$. Of the 14 questions analyzed (eight of perception and six of adherence), six of them obtained a kappa equal to 1.0 (the highest possible); another six obtained a kappa greater than 0.8 and lower than 1.0, considered very good; and only two obtained a kappa lower than 0.8 , with values of 0.79 and 0.45 .

In a Brazilian research that promoted the validation of an instrument on knowledge and self-care in heart failure, 14 questions were analyzed regarding the kappa coefficient. Five of them obtained total agreement, i.e., kappa equal to 1.0; seven obtained kappa greater than 0.6; one obtained kappa greater than 0.4; and one question obtained no agreement. Despite some unsatisfactory values, this study considered the instrument's reproducibility adequate, in view of the difference between the education level of its participants and of those who took part in the formulation of the original instrument ${ }^{(21)}$.
By considering that the adapted instrument did not obtain any questions with discordant kappa and that this test was not performed in the original instrument - which would allow a comparison between the two -, it is possible to ensure, to the Brazilian version, a high capacity to produce similar responses in different moments, a fact that gives it reproducibility and stability, considering the high ICC value ${ }^{(19)}$ and proportion of $85.8 \%$ of sentences with kappa between 0.8 and 1.0.

Another aspect evaluated in the reliability item was the internal consistency of the instrument, by Cronbach's alpha, with value of 0.57 . It is worth highlighting that this item was not evaluated in the original instrument ${ }^{(7)}$ nor in its Spanish version $^{(20)}$, because of the heterogeneity of answers in the 46 questions. The Dialysis Diet and Fluid non-adherence Questionnaire $(\mathrm{DDFQ})^{(9)}$ - instrument prepared in Europe in the late 1990s, which measures the adherence behavior of individuals in diet and water intake aspects - also did not have the instrument's internal consistency calculated.

Therefore, it was not possible to compare the alpha obtained in this study to any other that addresses scales of renal patients' adherence to treatment, because these are the only ones available in the world. We assign this value considered low $(0.57)$ to the fact that, although approaching the topic of adherence, the questions analyzed refer to different aspects of it. There is not necessarily a convergence of answers between respondents, because the individual non-adherent to HD, for example, can be quite adherent to water intake.

In the validation of an instrument on the adherence of HIVpositive patients to the antiretroviral therapy in Portugal, the obtained alpha was 0.70 . The questions (14), however, were all related to medication intake ${ }^{(22)}$. In the validation of an instrument that evaluated the adherence to oral anticoagulation therapy, in Brazil, the obtained Cronbach's alpha was 0.60, considered satisfactory for being an instrument with only six questions ${ }^{(23)}$. 
Therefore, we believe that, although the Cronbach's alpha obtained in this study is considered low, it is not sufficient to mischaracterize the instrument's internal consistency.

We evaluated both the reliability and validity of the instrument. We verified face, content, and construct validity. Face (or apparent) validity, both in this study and in the original and Spanish versions, was verified from the experts' agreement with the questions of the instrument $t^{(7,20)}$. This type of validity is considered the weakest between the three ${ }^{(19)}$.

In turn, content validation is a procedure focused on the participation of experts, who determine whether the questions put in the instrument are important to the topic which it proposes to approach and whether they comprise the universe of possible questions in the topic ${ }^{(19)}$. For content validation to be determined, the instrument must be submitted to at least five judges who shall assess the relevance of each item ${ }^{(24)}$.

In this study, nine experts analyzed the relevance of each item by assigning scores to them. CVI was calculated, reaching a value of 0.96 , which is close to that found in the original instrument, whose $\mathrm{CVI}$ ranged from 0.86 to 1.0 , with overall mean of 0.99 and evaluation from seven experts. It is also close to the Spanish version of the instrument, in which seven experts evaluated it by assigning an overall CVI of 0.98 , ranging from 0.97 to 0.99 . Except for the difference in the number of participating experts, the procedures of data collection, analysis and scores assigned to relevance were equal in the three versions ${ }^{(7,20)}$.

The DDFQ instrument ${ }^{(9)}$ had three experts for content validation, but did not establish a procedure for CVI calculation. In a research of validation of an instrument that measured cognitions related to weight checking, the researcher used nine experts for content validation, presenting his data in percentage. His results, however, showed a low level of agreement $(48.6 \%)$, which was attributed to the lack of conceptual domain of a little explored topic ${ }^{(25)}$. Such aspect reinforces the importance of a group of experts connected to the topic evaluated. Therefore, from the high CVI value achieved in this study, we can state that the questions addressed are relevant for approaching the topic of treatment adherence by chronic kidney disease patients on hemodialysis.

The last psychometric characteristic evaluated was construct validity. It is considered a main criterion for evaluating study quality, and is particularly indicated for measurement topics ${ }^{(19)}$. By the technique of known groups, we were able to separate patients between adherent and non-adherent in each domain and calculate the score obtained on the adherence questions.

In the HD domain, patients considered adherent obtained an average score of 967.45 points, against 694.00 points of non-adherent patients. In the medication domain, adherents obtained a score of 177.40 against 30 points of non-adherents. In the water intake domain, the score was 128.91 against 7.14 and, finally, in the diet domain, the score was 126.87 against 27.27. All domains presented $p<0.01$.

By the Mann-Whitney $U$ statistical test, we verified a significant association between the scores achieved by patients and their individual condition of adherent non-adherent in each domain, i.e., the instrument was able to distinguish the adherence behavior of individuals. The same occurred when the value of " $p$ " ranged between $\mathrm{p}<0.01 \sim 0.027$ in the original version ${ }^{(7)}$ of the instrument and between $p<0.01 \sim 0.028$ in the Spanish version ${ }^{(20)}$.

The main difficulties for comparing studies that measure adherence practice are: they use different instruments, which were not specifically built for the population of kidney patients; they use different markers, because these are not established in the literature ${ }^{(26)}$.

When comparing the adherence data between the three researches that used the same instrument (and based on the same markers) - this study, the original(7) and Spanish ${ }^{(20)}$ versions -, the values of non-adherence to HD were $32 \%, 22.4 \%$, and $7.6 \%$, respectively. For the medication domain, such values were $6.4 \%$, $5.1 \%$, and $5.7 \%$; for the water intake domain, $17.9 \%, 10.3 \%$, and $5.7 \%$; and for the diet domain, $14.1 \%, 12 \%$, and $19.2 \%$.

Therefore, we observed that the version adapted for Brazil can be considered valid, because the statistical tests attested the validity of its psychometric characteristics. However, one must consider that construct validity cannot be established by only one study. It requires a pattern of consistent findings involving different researchers for a significant period of time and with respect to different and theoretically relevant variables ${ }^{(27)}$.

\section{Study limitations}

One study limitation is on the methodological stage of data collection, in which the reading of the instrument by patients was established to avoid a possible influence of the researcher on the submitted answers. Thus, patients unable to text reading could not attend the research, which restricts the applicability of the instrument here validated.

The absolute number of patients on dialysis increases, on average, $3 \%$ per year in Brazil. These data give the dimension of the magnitude of chronic kidney disease in the Country, which has approximately 100,000 patients in renal replacement therapy, $90 \%$ of them on hemodialysis. Such reality points to the need for discussing and creating mechanisms that may contribute to the improvement of the morbidity and mortality rates of these individuals, still considered high in the Country, around $20 \%$. Therefore, bringing these patients to the centrality of their treatments, charging and inviting them to conscious adherence, must be considered a priority action of health systems.

\section{Contributions to the nursing field}

This study's contributions point to new research issues that may arise, and their exploration will feedback the production of knowledge in nursing, promoting a robust body of information on the topic in question. Thus, interventionist and comparative researches shall be developed to constantly promote treatment adherence for chronic renal disease patients submitted to hemodialysis.

\section{CONCLUSION}

The validation of the present instrument allows ensuring that it has good stability. Its internal consistency was not considered so high mainly because it approaches different aspects of the treatment. CVI was considered high and similar to that obtained in the original instrument, proving the relevance of the items that 
addressed the topic "adherence". We also verified the construct validation, which showed that the instrument has the capacity of distinguishing between adherent and non-adherent patients in all domains of the proposed treatment.
Thus, a technological instrument is now available to the Brazilian reality, assisting in the management of nursing care and in the promotion of adherence behavior of chronic renal disease patients on hemodialysis.

\section{REFERENCES}

1. Silva AS, Silveira RS, Fernandes GFM, Lunardi VL, Backes VMS. Percepções e mudanças na qualidade de vida de pacientes submetidos à hemodiálise. Rev Bras Enferm [Internet]. 2011 [cited 2015 Feb 28];64(5):839-44. Available from: http://www.scielo. $\mathrm{br} / \mathrm{pdf} / \mathrm{reben} / \mathrm{v} 64 \mathrm{n} 5$

2. Sesso RC, Lopes AA, Thomé FS, Lugon JR, Santos DR. Inquérito Brasileiro de Diálise Crônica 2013: análise das tendências entre 2011 e 2013. J Bras Nefrol [Internet]. 2014 [cited 2015 Jun 02]36(4):476-81. Available from: http://www.scielo.br/ pdf/jbn/ v36n4/0101-2800

3. Clark-Cutaia MN, Ren D, Hoffman LA, Burke LE, Sevick MA. Adherence to hemodialysis dietary sodium recommendations: influence of patient characteristics, self-efficacy and perceived barriers. J Ren Nutr [Internet]. 2014 [cited 2015 Nov 15];24(2):92_ 9. Available from: http://www.ncbi.nlm.nih.gov/pubmed/24462498

4. Sgnaolin V, Prado AE, Figueiredo L. Adesão ao tratamento farmacológico de pacientes em hemodiálise. J Bras Nefrol [Internet]. 2012 [cited 2015 Nov 15];34(2):109-16. Available from: http://www.scielo.br/pdf/jbn/v34n2/02.pdf

5. Khalil AA, Frazier SK, Lennie TA, Sawaya BP. Depressive symptoms and dietary adherence in patients with end-stage renal disease. J Ren Care [Internet]. 2011 [cited 2015 Nov 15];37(1):30-9. Available from: http://www.ncbi.nlm.nih.gov/pubmed/21288315

6. World Health Organization (WHO). Adherence to long-term therapies: evidence for action [Internet]. Geneva: WHO; 2003 [cited 2015 Jun 02]. Available from: http://www.who.int/chp/knowledge/publications/adherence_report/en/.

7. Kim Y, Evangelista LS, Philips LR, Pavlish C, Kopple JD. The end-stage renal disease adherence questionnaire (ESRD-AQ): testing the psychometric properties in patients receiving In-center hemodialysis. Nephrol Nurs J [Internet]. 2010 [cited 2015 Nov 15];37(4):777-93. Available from: http://www.ncbi.nlm.nih.gov/pmc/articles/PMC3077091/.

8. Lins SMSB. Adaptação cultural e validação do questionário de avaliação sobre a adesão do portador de doença renal crônica em hemodiálise: uma contribuição para a gerência do cuidado de enfermagem. Rio de Janeiro. [Tese]. Escola de Enfermagem. Universidade Federal do Rio de Janeiro, 2015.

9. Vlaminck H, Maes B, Jacobs A, Reyntjens S, Evers G. The dialysis diet and fluid non-adherence questionnaire: validity testing of a self-report instrument for clinical practice. J Clin Nurs [Internet]. 2001 [cited 2015 Jun 02];10(5):707-15. Available from: http:// www.ncbi.nlm.nih.gov/pubmed/11822521

10. Pinheiro J. Autonomia e aderência na pessoa com doença renal crônica. Rev Bioét [Internet]. 2011 [cited 2015 Jun 02];19(1):21929. Available from: http://www.revistabioetica.cfm.org.br/index.php/revista bioetica/article/viewFile/616/633

11. Saran R, Bragg-Gresham JL, Rayner HC, Goodkin DA, Keen ML, Van Dijk PC, et al. Nonadherence in hemodialysis: associations with mortality, hospitalization, and practice patterns in the DOPPS. Kidney Int [Internet]. 2003 [cited 2014 Aug 28];64(1):254-62. Available from: http://www.ncbi.nlm.nih.gov/pubmed/12787417

12. Brasil. Ministério da Saúde. Portaria n ${ }^{\circ}$ 389, de 13 de março de 2014. Define os critérios para a organização da linha de cuidado da Pessoa com Doença Renal Crônica (DRC) e institui incentivo financeiro de custeio destinado ao cuidado ambulatorial pré-dialítico [Internet]. 2014 [cited 2015 Jun 02]; Available from: http://bvsms.saude.gov.br/bvs/saudelegis/gm/2014/prt0389 13032014. html

13. National Kidney Foundation (NKF). Updates clinical practice guidelines and recommendations [Internet]. EUA: NKF; 2006 [cited 2015 Jun 02]. Available from: https:// www.kidney.org/sites/default/files/docs/12-50-0210_jag_dcp_guidelines-hd_oct06_sectiona

14. Brasil. Ministério da Saúde. Agenda Nacional de Prioridades de Pesquisa em Saúde [cited 2015 Feb 28 ]; 2008 [cited 2015 Feb 28]. Available from: http://bvsms.saude.gov.br/bvs/publicacoes/agenda nacional prioridades

15. Sapnas KG, Zeller RA. Minimizing sample size when using exploratory factor analysis for measurement. J Nurs Meas [Internet]. 2002 [cited 2015 Jun 02];10(2):135-54. Available from: http://www.ncbi.nlm.nih.gov/pubmed/12619534

16. Snedecor GW, Cochran WG. Statistical Methods. 6. Ed. lowa: The lowa State University Press, 1972.

17. Landis RJ, Koch GG. The Measurement of Observer Agreement for Categorical Data. Biometrics 1977; 33:59-174.

18. Almeida D, Santos MAR, Costa, AFB. Aplicação do coeficiente alfa de cronbach nos resultados de um questionário para avaliação de desempenho da saúde pública. In: XXX Encontro Nacional de Engenharia de Produção, 2010 out 10-15; São Paulo, Brasil. São Paulo: Associação Brasileira de Engenharia de Produção; 2010. p 1-12. Available from: http://www.abepro.org.br/biblioteca/ enegep2010_TN_STO_131_840_16412.pdf

19. Polit DF, BecK CT. Fundamentos da pesquisa em Enfermagem. 7.ed. Porto Alegre: Artmed, 2011. 
20. Kim Y, Evangelista LS. Development and cultural adaptation of the Spanish version of the End Stage Renal Disease Adherence Questionnaire (SESRD-AQ). Nephrol Nurs J [Internet]. 2013 [cited 2015 Jun 02];40(6):493-506. Available from: http://www.ncbi. $\mathrm{nlm} / 24579396$

21. Rabelo ER, Mantovani VM, Aliti GB, Domingues FB. Adaptação transcultural e validação de um questionário de conhecimento da doença e autocuidado, para uma amostra da população brasileira de pacientes com insuficiência cardíaca. Rev Latino-Am Enfermagem [Internet]. 2011 [cited 2015 Feb 28]; 10(2). Available from: http://www.scielo.br/pdf/rlae/v19n2/pt_08.pdf

22. Reis AC, Lencastre L, Guerra MP, Remor E. Adaptação portuguesa do questionário para a avaliação da adesão ao tratamento Antiretrovírico - vih (ceat-vih). Psicol Saúde Doenças [Internet]. 2009 [cited 2015 Nov 15];10(2). Available from: http://www.scielo. mec.pt/pdf/psd/v10n2/v10n2a02.pdf

23. Carvalho ARS, Dantas RAS, Pelegrino FM, Corbi ISA. Adaptation and validation of an oral anticoagulation measurement of treatment adherence instrument. Rev Latino-Am Enfermagem [Internet]. 2012 [cited 2015 Jun 02];18(3):301:8. Available from: http://www.revistas.usp.br/rlae/article/view/4155/5106

24. Alexandre NMC, Coluci MZO. Validade de conteúdo nos processos de construção e adaptação de instrumentos de medidas. Ciênc Saúde Colet [Internet]. 2011 [cited 2015 Jun 02];16(7):3061-8 Available from: http://www.scielo.br/pdf/csc/v16n7/06.pdf

25. Kachani AT, Barbosa ALR, Brasiliano S, Cotdás TA, Hocgraf PB, Conti MA. Tradução, adaptação transcultural para o português (Brasil) e validação de conteúdo da Body Checking Cognitions Scale (BCCS). Rev Psiq Clín [Internet]. 2011 [cited 2015 Jun 02];38(1). Available from: http://www.scielo.br/pdf/rpc/v38n1/a04v38n1.pdf

26. Cicolini G, Palma E, Simonetta C, Nicola M. Influence of family carers on haemodialyzed patients' adherence to dietary and fluid restrictions: an observational study. J Adv Nur [cited 2015 Jun 02];68(11):2410-7. Available from: http://www.ncbi.nlm.nih.gov/ pubmed/22360845

27. Pasquali L. Validade dos testes psicológicos: será possível reencontrar o caminho? Psicol: Teor Pesq [Internet]. 2007 [cited 2015 Nov 15];23(spe):99-107. Available from: http://www.scielo.br/pdf/ptp/v23nspe/18 